Abstract THU0196 - Table 1. Hazardratios among patients starting their first biologic treatment during the studyperiod according to contextual factors

\begin{tabular}{|c|c|c|c|c|}
\hline & $\begin{array}{l}\text { Infliximab } \\
\text { originator }\end{array}$ & $\begin{array}{l}\text { Infliximab } \\
\text { biosimilar }\end{array}$ & $\begin{array}{l}\text { Etanercept } \\
\text { originator }\end{array}$ & $\begin{array}{l}\text { Etanercept } \\
\text { biosimilar }\end{array}$ \\
\hline Number of patients & 368 & 738 & 125 & 2079 \\
\hline $\begin{array}{l}\text { Number of } \\
\text { discontinuations }\end{array}$ & 165 & 265 & 23 & 392 \\
\hline \multicolumn{5}{|l|}{ Dept. size } \\
\hline Low (quartile | \& II) & $0.88(0.37-2.11)$ & $1.47(0.88-2.46)$ & $30.66(6.16-152.68)$ & $1.69(1.12-2.55)$ \\
\hline Medium (quartile III) & $1.29(0.81-2.08)$ & $1.90(1.36-2.65)$ & $10.96(2.13-56.49)$ & $1.40(1.08-1.82)$ \\
\hline High (quartile IV) & Ref & Ref & Ref & Ref \\
\hline \multicolumn{5}{|l|}{ Dept. use of biosimilars } \\
\hline Low & Ref & Ref & Ref & Ref \\
\hline High & $0.88(0.58-1.34)$ & $1.20(0.82-1.75)$ & $1.90(0.64-5.70)$ & $1.00(0.77-1.29)$ \\
\hline \multicolumn{5}{|l|}{ Period of biologic start* } \\
\hline Early period & Ref & Ref & Ref & Ref \\
\hline & $0.98(0.67-1.42)$ & $0.65(0.50-0.85)$ & $0.06(0.01-0.53) \S$ & $0.76-1.17)$ \\
\hline
\end{tabular}

*Additionally adjusted for department size and use of biosimilar;

$\S$ Only 2 discontinuation in the later period of etanercept originator

Conclusions: Contextual factors, presumably related to expectations and differences in clinical monitoring, influence the observed survival on drug of biologics, including biosimilars, and must be considered when the comparative effectiveness of biosimilars is evaluated.

Disclosure of Interest: D. DiGiuseppe: None declared, T. Frisell: None declared, E. Lindqvist: None declared, L. Jacobsson Consultant for: received lecture and consulting fees from Pfizer, Abbvie and Novartis, C. Turesson Grant/ research support from: Abbvie, Bristol Myers-Squibb, Roche, Consultant for: MSD, Bristol Myers-Squibb, Roche, Paidinstructor for: Abbvie, Bristol-Myers Squibb, Janssen, MSD, Pfizer, Roche and UCB, C. Sjöwall: None declared, J. Askling Grant/research support from: has orhas had research agreements with Abbvie, BMS, MSD, Pfizer, Roche, Astra-Zeneca, Eli Lilly, Samsung Bioepis, and UCB, mainly in the context of safety monitoring of biologics via ARTIS. Karolinska Institutet has received remuneration for JA participating in advisory boards arranged by Pfizer and Eli Lilly.

DOI: 10.1136/annrheumdis-2018-eular.4464

\section{THU0197 EFFECTS OF TOCILIZUMAB, AN ANTI-INTERLEUKIN-6 RECEPTOR ANTIBODY, ON SERUM LIPID AND ADIPOKINE LEVELS IN PATIENTS WITH RHEUMATOID ARTHRITIS}

E. Hoffman ${ }^{1}$, M.A. Rahat ${ }^{1,2}$, J. Feld ${ }^{3}$, M. Elias ${ }^{3}$, I. Rosner ${ }^{1,4}$, L. Kaly ${ }^{4}$, I. Lavi ${ }^{5}$, D. Zisman ${ }^{1,3} .{ }^{1}$ The Ruth and Bruce Rappaport Faculty of Medicine, Technion; ${ }^{2}$ The Immunotherapy Laboratory; ${ }^{3}$ Rheumatology Unit, Carmel Medical Center, ${ }^{4}$ Rheumatology Unit, Bnai Zion Medical Center, ${ }^{5}$ Department of Community Medicine and Epidemiology, Carmel Medical Center, Haifa, Israel

Background: Patients with rheumatoid arthritis (RA) are at increased risk of cardiovascular disease. ${ }^{1}$ Dyslipidemia is a known adverse reaction to tocilizumab (TCZ), the anti-interleukin-6 receptor antibody, used in RA treatment.

Objectives: To assess the effect of TCZ on lipid and adipokine levels in the serum of RA patients

Methods: Forty RA patients with active disease initiating TCZ treatment and 40 healthy matched controls were included. Height, weight, disease activity score (DAS28), lipid profile and atherogenic indices (AI) were measured before and four months after TCZ treatment initiation. Serum concentrations of leptin, adiponectin, resistin, interleukin- 6 and high sensitivity CRP were measured by ELISA in both study groups.

Statistical analysis: The differences in clinical and laboratory data of RA patients between baseline and follow up were assessed by paired t-test and by linear mixed models with repeated measures for adipokines levels after adjustment to BMI, statin treatment and disease duration. To compare the adipokines levels between RA and control groups adjusted to baseline BMI and statin treatment we used ANCOVA models. HsCRP and IL- 6 were compared between the two groups by two-tailed Mann Whitney test. The results were considered statistically significant when $\mathrm{p} \leq 0.05$.

Results: The average age of the study population was $57.5 \pm 11$ years, $82.5 \%$ were women, with a disease duration of $8.7 \pm 5.6$ years. The majority of the patients responded to TCZ and reduced their diseases activity from DAS28 score of 5.45 \pm 1.06 to $3.46 \pm 1.37$ ( $p<0.0001)$. Following treatment, a significant elevation of total cholesterol $(199 \pm 52$ to $221 \pm 53 \mathrm{mg} / \mathrm{dl}, \mathrm{p}<0.01)$, HDL $(55 \pm 19$ to $59 \pm 23 \mathrm{mg} / \mathrm{dl}$, $\mathrm{p}<0.01)$ and triglycerides $(140 \pm 69$ to $168 \pm 107, p=0.04)$, and no significant changes in weight, BMI, low density lipoprotein (LDL) and Al were found. Significantly higher adiponectin levels $(5.59 \pm 2.39 \mathrm{vs}$. $3.75 \pm 1.63 \mathrm{ng} / \mathrm{ml}, \mathrm{p}<0.0001)$, lower resistin levels $(16.25 \pm 7.17$ vs. $21.53 \pm 8.19 \mathrm{pg} / \mathrm{ml}, p=0.007)$ and leptin/adiponectin ratio $(6.44 \pm 6.44$ vs.5.52 $\pm 6.08, p=0.03)$ were measured in the RA group compared to controls after adjustment to BMI and statin treatment. Four months after TCZ treatment a statistically significant decrease in adiponectin (4.53 $\pm 2.12 \mathrm{ng} / \mathrm{ml} \mathrm{p}<0 / 0001)$, resistin levels $(20.42 \pm 8.06 \mathrm{pg} / \mathrm{ml}, \mathrm{p}=0.01)$ and leptin/adiponectin ratio $(7.99 \pm 7.84, p=0.002)$ were measured after adjustment to BMI, statin treatment and disease duration. The levels of hsCRP decreased significantly
(3.37 \pm 2.0 vs $0.74 \pm 1.36 \mathrm{mg} / \mathrm{dl}, \mathrm{p}<0.001)$ and IL-6 increased significantly $(13.15$ \pm 25.43 vs $99.80 \pm 97.97 \mathrm{pg} / \mathrm{ml}, \mathrm{p}<0.001$ ) following treatment.

Conclusions: The impact of TCZ treatment on lipid metabolism is complex. The elevation in $\mathrm{HDL}$ without change in $\mathrm{Al}$, and the tendency toward normalisation of the adipokine profile observed, suggests a protective role of TCZ treatment against the cardiovascular burden in RA patients.

\section{REFERENCE:}

[1] Lago F, Gomez R, et al. Cardiometabolic comorbidities and rheumatic diseases: focus on the role of fat mass and adipokines. Arthritis Care Res $2011 ; 63: 1083-90$

Disclosure of Interest: None declared

DOI: 10.1136/annrheumdis-2018-eular.4418

\section{THU0198 IMMUNOGENICITY ASSOCIATED WITH A TRANSITION FROM ADALIMUMAB REFERENCE PRODUCT TO ABP 501 IN PATIENTS WITH RHEUMATOID ARTHRITIS}

E. Krishnan, D. Mytych, N. Zhang, H. Wang, A. Kaliyaperumal. Biosimilars Development, Amgen Inc., Thousand Oaks, USA

Background: In clinical practice, patients treated with an originator product may be transitioned to a biosimilar. Therefore, it is important to ensure that such transition is safe and is not associated with increased immunogenicity.

Objectives: To study the incidence of binding anti-drug antibodies (bADAs) and neutralising anti-drug antibodies (nADAs) after patients with rheumatoid arthritis (RA) are transitioned from adalimumab reference product (RP) to ABP 501, an approved biosimilar for adalimumab.

Methods: We analysed data from the open-label extension (OLE) of a randomised 26 week phase 3 study (NCT 01970475) comparing ABP 501 and adalimumab. In this OLE study (NCT02114931), patients originally randomised to ABP 501 in the parent study continued on ABP 501 while patients originally randomised to adalimumab (RP) were switched to ABP 501 so that all patients received ABP 501. Specifically, we studied the incidence of new ADAs in patients who were ADA negative at the time of entry into the OLE study. The incidence after excluding transiently elevated ADAs was also examined.

Results: The Table summarises the incidence of ADAs.

Abstract THU0198 - Table 1

\begin{tabular}{|l|c|c|}
\hline Original randomization arm & $\begin{array}{c}\text { ABP 501/ } \\
\text { ABP 501 }\end{array}$ & $\begin{array}{c}\text { Adalimumab RF/ } \\
\text { ABP 501 }\end{array}$ \\
\hline $\begin{array}{l}\text { Number of patients with negative bADA at } \\
\text { oLE baseline }\end{array}$ & 147 & 149 \\
\hline New oases of +bADA post OLE baseline & 50 & 35 \\
\hline New cases of +nADA post OLE baseline & 20 & 12 \\
\hline Transient cases of +bADA & 33 & 13 \\
\hline Transient cases of + nADA & 8 & 2 \\
\hline Overall incidence of new cases of +bADA & $34.0 \%$ & $23.5 \%$ \\
\hline Overall incidence of new cases of +nADA & $13.6 \%$ & $8.1 \%$ \\
\hline Incidence of non-transient cases of +bADA & $11.6 \%$ & $14.8 \%$ \\
\hline Incidence of non-transient cases of +nADA & $8.2 \%$ & $6.7 \%$ \\
\hline
\end{tabular}

Conclusions: Transitioning from adalimumab reference product to ABP 501 was not associated with increased immunogenicity over the observational period of 72 weeks.

Disclosure of Interest: E. Krishnan Shareholder of: Amgen Inc., Employee of: Amgen Inc., D. Mytych Shareholder of: Amgen Inc., Employee of: Amgen Inc., N. Zhang Shareholder of: Amgen Inc., Employee of: Amgen Inc., H. Wang Shareholder of: Amgen Inc., Employee of: Amgen Inc., A. Kaliyaperumal Shareholder of: Amgen Inc., Employee of: Amgen Inc.

DOI: 10.1136/annrheumdis-2018-eular.7225

\section{THU0199 A PILOT STUDY TO ASSESS THE RELATIONSHIP BETWEEN SMOKING AND DRUG INEFFICACY IN RHEUMATOID ARTHRITIS - PART OF A QUALITY IMPROVEMENT PROJECT AIMED AT SMOKING CESSATION}

G. Starritt, D. Brennan. Rheumatology, Musgrave Park Hospital, Belfast Health and Social Care Trust, Belfast, UK

Background: It has long been known that patients with rheumatoid arthritis who smoke have more severe disease. This results in greater joint destruction and dis ability, and further increase in cardiovascular risk ${ }^{1}$. Patients' disease may be more difficult to control with disease modifying anti-rheumatic drugs (DMARDs) and biologic drugs. Smoking may also interfere with the pharmacokinetics of biologic 
drugs $^{2}$. Clinicians could then cycle through more of these expensive drugs because of inefficacy. As a modifiable risk factor smoking should be targeted to improve outcomes for patients.

Objectives: To complete a pilot study examining for an association between smoking and drug inefficacy in rheumatoid arthritis. This baseline data was used in a quality improvement project aimed at reducing the prevalence of smoking in our rheumatology patients.

Methods: We identified patients using a dataset and a database including all patients currently receiving biologics in Musgrave park hospital. Each patient had a diagnosis of rheumatoid arthritis and was being treated with a biologic. We randomly selected 100 patients with rheumatoid arthritis, 50 of whom were current smokers and 50 non-smokers. We then performed a search on Northern Ireland's electronic care record for each patient and identified how many DMARDs and biologics were discontinued due to inefficacy. Inefficacy was defined as ongoing synovitis despite receiving the drug at adequate dosage for 3-6 months resulting in the drug being discontinued. We also identified patients who received rituximab and the number of patients for which it was stopped due to inefficacy.

Results: DMARDs and inefficacy: non-smokers had on average 0.98 stopped and smokers had on average 2.2 stopped. Biologics and inefficacy: non-smokers had on average 0.5 stopped and smokers had on average 0.82 stopped. Twenty smokers and twenty non-smokers were treated with rituximab. Non-smokers: 4 out of 20 had rituximab discontinued due to inefficacy. Smokers: 8 out of 20 had rituximab discontinued due to inefficacy.

Conclusions: In this small sample of patients, we found that smokers had greater DMARD and biologic inefficacy, particularly with rituximab where smokers had double the rate of inefficacy compared to non-smokers. Our quality improvement project aims to reduce the prevalence of smoking in our rheumatology patients which could result in better disease control, reduction in cardiovascular risk, and less drugs being cycled through. Aiming to achieve this, steps have been taken to set up a rheumatology smoking cessation clinic in our health trust.

\section{REFERENCES:}

[1] Saevarsdottir S, Rezaei H, Geborek P, Petersson I, Ernestam S, Albertsson $\mathrm{K}$. Current smoking status is a strong predictor of radiographic progression in early rheumatoid arthritis: results from the SWEFOT trial. Ann Rheum Dis 2015;74(8):1509-14.

[2] Chang K, Yang SM, Kim SH, Han KH, Park SJ, Shin JI. Smoking and rheumatoid arthritis. Int J Mol Sci 2014;15(12):22279-95

Disclosure of Interest: None declared

DOI: 10.1136/annrheumdis-2018-eular.7345

\section{THU0200 SUBCUTANEOUS TOCILIZUMAB IN PATIENTS WITH RHEUMATOID ARTHRITIS; A HIGH NUMBER OF PATIENTS ACHIEVE DOPPLER REMISSION AFTER 24 WEEKS}

H.B. Hammer ${ }^{1}$, I.M.J. Hansen ${ }^{2}$, P. Jarvinen ${ }^{3}$, M. Leirisalo-Repo ${ }^{4}$, M. Ziegelasch ${ }^{5}$ B. Agular ${ }^{6}$, L. Terslev ${ }^{7}{ }^{1}$ Dept Of Rheumatology, Diakonhjemmet Hospital, Oslo, Norway, ${ }^{2}$ Dept of rheumatology, Svendborg Hospital, Svendborg, Denmark; ${ }^{3}$ Dept of rheumatology, Kiljavan Lääketutkimus, Kiljavan; ${ }^{4}$ Dept of rheumatology, Helsinki University Hospital and University, Helsinki, Finland; ${ }^{5}$ Dept of rheumatology, University Hospital, Linköping, Sweden; ${ }^{6}$ Med.dept, Roche; ${ }^{7}$ Centre for Rheumatology and Spinal Diseases, Copenhagen University Hospital at Glostrup, Copenhagen, Denmark

Background: Clinical remission in rheumatoid arthritis (RA) is evaluated by Com posite Disease Activity Scores (CDAS) including DAS28 and CDAI. Ultrasound (US) is more sensitive than clinical examination for detection of synovitis and assessed by use of Grey Scale (GS) and vascularisation by power/colour Doppler.

Objectives: To explore the number of patients reaching Doppler compared to CDAS remission in moderate to severe biologically naïve RA patients (pts) treated with subcutaneous tocilizumab (TCZ-SC) over 24 weeks and to evaluate the safety of TCZ-SC.

Methods: A regional multi-country (Denmark, Finland, Norway, Sweden) openlabel, single-arm study (part of TOZURA ${ }^{1}$ ), enrolled pts with inadequate response to csDMARDs. Pts received TCZ-SC $162 \mathrm{mg}$ qw for 24 weeks as monotherapy or in combination with a csDMARD. Stable oral NSAIDs and corticosteroids (CS) ( $\leq 10 \mathrm{mg} /$ day prednisone or equivalent), were allowed. Clinical (tender and swollen joints), laboratory tests, safety assessments as well as US examination (36 joints and 4 tendons, scored according to the Norwegian US atlas ${ }^{2}$ ) were performed at baseline, 4, 12 and 24 weeks. US reliability between centres was assessed prior to the study. There is no consensus on definitions of Doppler remission, and Doppler sum scores of 0 to 3 were presently explored as definitions of US remission. CDAS and EULAR/ACR Boolean remission were calculated.
Results: 133 pts were included, and 110 pts were followed with US assessments (83\% female, mean (SD) age 55.6 (12.1) years and RA duration 8.7 (9.5) years, $81 \%$ anti-CCP positive and $62 \%$ with erosive disease). All clinical, laboratory and US variables decreased significantly, already after 4 weeks $(p<0.001)$ (table 1) Table 2 illustrates the high percentages of patients reaching remission, especially for DAS28(ESR) and Doppler. Fourteen serious AE were reported in 12 pts and 15 AEs led to permanent withdrawal of treatment.

\begin{tabular}{|c|c|c|c|c|}
\hline & $\begin{array}{l}\text { Baseline } \\
\text { Median } \\
\text { (IQR) } n=110\end{array}$ & $\begin{array}{l}4 \text { weeks } \\
\text { Median } \\
(\text { IQR }) \\
n=102\end{array}$ & $\begin{array}{c}12 \text { weeks } \\
\text { Median (IQR) } n=95\end{array}$ & $\begin{array}{c}24 \text { weeks } \\
\text { Median } \\
(\text { IQR) } \\
n=91\end{array}$ \\
\hline DAS28(ESR) & $\begin{array}{l}5.0(4.3- \\
5.8)\end{array}$ & $\begin{array}{c}3.1(2.1- \\
3.8)\end{array}$ & $2.1(1.5-2.9)$ & $\begin{array}{c}1.6(1.1- \\
2.4)\end{array}$ \\
\hline CDAI & $\begin{array}{c}23.8(17.1- \\
31.2)\end{array}$ & $\begin{array}{c}12.9(7.3- \\
21.9)\end{array}$ & $7.2(3.6-11.4)$ & $\begin{array}{c}4.3(1.8- \\
9.8)\end{array}$ \\
\hline CRP & $\begin{array}{c}5.5(2.6- \\
13.1)\end{array}$ & $\begin{array}{c}0.2(0.2- \\
0.4)\end{array}$ & $0.2(0.2-0.6)$ & $\begin{array}{c}0.2(0.2- \\
0.4)\end{array}$ \\
\hline ESR & $21(12-34)$ & $4(2-7)$ & $3(2-5)$ & $3(2-5)$ \\
\hline Patient's global VAS $(0-100)$ & $55(36-70)$ & $\begin{array}{c}32(18- \\
49)\end{array}$ & $16(7-31)$ & $12(4-28)$ \\
\hline Assessor's global VAS $(0-100)$ & $35(25-49)$ & $\begin{array}{c}17(11- \\
31)\end{array}$ & $10(5-18)$ & $5(2-11)$ \\
\hline Tender joint count & $8(5-12)$ & $4(1-9)$ & $2(0-5)$ & $1(0-3)$ \\
\hline Swollen joint count & $6(2-10)$ & $2(0.5-6)$ & $1(0-2.5)$ & $0(0-2)$ \\
\hline Sum score GS & $21(13-36)$ & $16(8-30)$ & $12(5-21)$ & $9(3-19)$ \\
\hline Sum score PD & $8(2-20)$ & $4(1-10)$ & $1(0-4)$ & $0(0-2)$ \\
\hline Remission criteria & \multicolumn{2}{|c|}{$\begin{array}{l}\text { Percentages } \\
\text { of Pts in } \\
\text { remission at } \\
12 \text { weeks }\end{array}$} & \multicolumn{2}{|c|}{$\begin{array}{l}\text { Percentages of Pts in } \\
\text { remission at } 24 \text { weeks }\end{array}$} \\
\hline CDAI & \multicolumn{2}{|c|}{19.2} & \multicolumn{2}{|l|}{34.7} \\
\hline DAS28(ESR) & \multicolumn{2}{|c|}{64.6} & \multicolumn{2}{|l|}{83.5} \\
\hline Boolean & \multicolumn{2}{|c|}{14.0} & \multicolumn{2}{|l|}{27.4} \\
\hline PD sum score $=0$ & \multicolumn{2}{|c|}{42.6} & \multicolumn{2}{|l|}{53.3} \\
\hline PD sum score $\leq 1 / \leq 2 / \leq 3$ & \multicolumn{2}{|c|}{$60.6 / 68.1 / 73.4$} & \multicolumn{2}{|l|}{$65.6 / 75.6 / 78.9$} \\
\hline
\end{tabular}

Conclusions: This open label study showed TCZ-SC to significantly reduce inflammation assessed by both CDAS and Doppler US. A high number of pts (53\%-79\%) obtained Doppler remission at 24 weeks using the different definitions. The safety profile was similar to what has previously been reported.

REFERENCES:

[1] EULAR 2017 Abstract SAT0199.

[2] Hammer HB, et al. ARD 2011.

Disclosure of Interest: None declared

DOI: 10.1136/annrheumdis-2018-eular.3533

\section{THU0201 A POOLED ANALYSIS OF THREE TNF-A INHIBITOR BIOSIMILAR STUDIES IN PATIENTS WITH RHEUMATOID ARTHRITIS COMPARING RADIOGRAPHIC PROGRESSION BY DISEASE ACTIVITY STATES}

J.S. Smolen ${ }^{1}$, M. Weinblatt ${ }^{2}$, P. Emery ${ }^{3}$, E. Keystone ${ }^{4}$, M. Genovese ${ }^{5}$, G. Myung ${ }^{6}$, E. Hong ${ }^{6}$, I. Baek ${ }^{6}$, S. Lee ${ }^{6}$, J. Ghil ${ }^{6}$. ${ }^{1}$ Medical University of Vienna, Vienna, Australia; ${ }^{2}$ Brigham and Women's Hospital, Boston, USA; ${ }^{3}$ Leeds Institute of Rheumatic and Musculoskeletal Medicine, Leeds, UK; ${ }^{4}$ Mount Sinai Hospital, Toronto, Canada; ${ }^{5}$ Stanford University Medical Center, Stanford, USA; ${ }^{6}$ Samsung Bioepis Co., Ltd., Incheon, Korea, Republic of Ireland

Background: SB4, SB2, and SB5 are biosimilars of the reference etanercep (ETN), infliximab (INF), and adalimumab (ADA), respectively. Radiographic progression using the modified Total Sharp Score (mTSS) at week 0 and final week (week 52 for etanercept and adalimumab and week 54 for infliximab) was measured in phase III randomised, double-blind studies comparing efficacy and safety of biosimilar to its reference product.

Objectives: Assess and compare radiographic progression by disease activity states at week 24 (for etanercept and adalimumab) or week 30 (for infliximab) in terms of DAS28 from a pooled analysis of three biosimilar studies. ${ }^{1-3}$

Methods: Patients with radiographic data from each phase III study were pooled and grouped based on their disease activity state (remission, low disease activity [LDA], moderate disease activity [MDA], and high disease activity [HDA]) at week 24 or 30 in terms of DAS28. The mean change in mTSS and the proportion of radiographic non-progressors of higher disease activity groups (LDA, MDA, and $\mathrm{HDA}$ ) in reference to remission were summarised descriptively and odds ratios (OR) were compared using 95\% confidence interval $(\mathrm{Cl})$ obtained from logistic model with baseline DAS28. 